\title{
lukman hakim
}

Sekolah Tinggi Ilmu Ekonomi Syariah Bengkalis

e-mail: lukman_hakim94@ymail.com

\section{ARTICLE INFO}

Article history:

Received 30 September 2021

Received in revised form 2 November 2021

Accepted 10 November 2021

Available online 1 Desember 2021

\begin{abstract}
This study was conducted to determine the effect of non-performing loans and the effect of bank interest rates on the performance of a bank with net income in the range of 2013 to 2019. This study uses SPSS and interviews as primary instruments in obtaining and analyzing data, the results of this study is that NPL has no significant effect on Bank Mega's net profit, and Bank Indonesia's interest rate also does not have a significant effect on Bank Mega's net profit, then it is also found that NPL and Bank Indonesia's Interest Rate simultaneously contribute 9.3\% to profit Bank Mega's net and the remaining $90.7 \%$ is influenced by other unknown factors.
\end{abstract}

Keywords: Non Performing Loan, Bank Indonesia interest rate, net profit

\section{Introduction}

Bank merupakan lembaga keuangan yang menghimpun dana dari masyarakat dan menyalurkannya kepada masyarakat terutama dalam bentuk kredit serta memberikan jasa-jasa perbankan baik dalam maupun luar negeri. (Riyadi, Iqbal, \& Lauren, 2015). Suku bunga tersebut ditetapkan oleh otoritas moneter yaitu Bank Indonesia selaku bank sentral, sehingga cenderung disebut sebagai BI Rate atau tingkat suku bunga Bank Indonesia (Sudirman, 2011). kemakmuran masyarakat secara keseluruhan pada gilirannya akan mengalami penurunan. Kondisi tersebut antara lain melatar-belakangi upaya-upaya yang dilakukan oleh pemerintah atau otoritas moneter suatu negara dalam mengendalikan jumlah uang beredar dalam perekonomian. Kegiatan pengendalian jumlah uang beredar tersebut lazimnya disebut dengan kebijakan moneter (Warjiyo \& Solikin, 2003).

Jika pada suatu saat, suku bunga uang menunjukkan kenaikan hingga melampaui angka yang ditetapkan, maka Bank Sentral akan segera melakukan kebijakan ekspansi moneter sehingga tingkat suku bunga uang menjadi turun kembali sampai pada tingkat suku bunga yang ditetapkan. Jika tingkat suku bunga uang menunjukkan penurunan hingga dibawah angka yang ditetapkan, maka Bank Sentral akan egera melakukan kebijakan moneter kontraktif sehingga tingkat suku bunga uang naik kembali sampai pada tingkat suku bunga yang ditetapkan atau sebaliknya. Perkembangan tingkat bunga uang yang tidak wajar akan secara langsung menyebabkan terganggunya lembaga keuangan bank. Dengan suku bunga uang yang tinggi akan mendorong 
masyarakat untuk menyimpan dananya di bank sehingga bank memiliki dana yang sangat besar sehingga kemampuan bank menyalurkan kredit juga menjadi besar. Bersamaan dengan kondisi tersebut, suku bunga kredit juga akan meningkat sehingga hasrat masyarakat untuk meminjam kredit di bank menjadi menurun karena bunga kredit yang tinggi merupakan biaya dana yang tinggi dalam suatu investasi. Tingkat bunga uang yang tinggi, investasi menurun menyebabkan jumlah produksi menurun sehingga pendapatan masyarakat akan menurun. Sebaliknya, tingkat suku bunga yang terlalu rendah dibanding dengan tingkat bunga di luar negeri akan mengurangi hasrat masyarakat untuk menyimpan dana di dalam negeri atau masyarakat cenderung menyimpan dananya di luar negeri sehingga menyulitkan bank-bank menghimpun dana masyarakat di balik meningkatnya hasrat masyarakat untuk meminjam kredit di bank (Ayerza, 2018).

Disamping dari tingkat suku bunga Bank Indonesia, penulis juga menemukan sebuah teori oleh Deasy Dwihandayani tahun 2007 dalam jurnalnya yang berjudul "Analisis Kinerja Non Performing Loan (NPL) Perbankan di Indonesia dan faktor-faktor yang mempengaruhi NPL" (Volume 22 No.3) yang menyatakan bahwa "NPL adalah satu indikator kunci untuk menilai kinerja fungsi bank, karena NPL yang tinggi adalah indikator gagalnya bank dalam mengelola bisnis antara lain timbul masalah likuiditas, rentabilitas, dan solvabilitas. Laba yang merosot adalah salah satu imbasnya karena praktis bank kehilangan sumber pendapatan disamping harus menyisihkan pencadangan sesuai kolektibilitas kredit. Sementara penelitian oleh Ayu Shauma Fitriyani yang berjudul "Pengaruh Non Performing Loan (Npl) terhadap Laba Pada PT. Bank Rakyat Indonesia (Persero) Tbk Unit Karanganyar Kantor Cabang Tegal" menemukan bahwa tingkat NPL berpengaruh signifikan secara negatif terhadap NPL dan berkontribusi sebesar 9,9\% terhadap laba bersih bank BRI sementara sisa 90,9\% dipengaruhi oleh faktor lainnya (Fitriyan, 2016).

Penelitian oleh Yohan Henri Wibowo, di dalam jurnalnya yang berjudul "Hubungan Antara Rasio Kredit Bermasalah dengan Rasio Profitabilitas: Studi Empiris pada BPR Se-Kota Tangerang Periode 2015" yang menjelaskan bahwa tidak ditemukan bukti empiris yang dapat menjelaskan hubungan yang signifikan antara Rasio Kredit Bermasalah yang terefleksikan pada indikator NPL dengan Rasio Profitabilitas yang terefleksikan pada indikator NPM pada BPR seKota Tangerang (Wibowo., 2017).

Tabel .1

Data NPL, Tingkat Suku Bunga Bank Indonesia, dan Laba bersih bank Mega

\begin{tabular}{|c|c|c|c|}
\hline Tahun & NPL Bank Mega & $\begin{array}{c}\text { Tingkat Suku } \\
\text { Bunga Bank } \\
\text { indonesia }\end{array}$ & $\begin{array}{c}\text { Laba Bersih Bank } \\
\text { Mega } \\
\text { (miliar Rupiah) }\end{array}$ \\
\hline 2013 & $2,18 \%$ & $6,48 \%$ & 525 \\
\hline 2014 & $2,09 \%$ & $7,54 \%$ & 568 \\
\hline 2015 & $2,81 \%$ & $7,52 \%$ & 1053 \\
\hline 2016 & $3,44 \%$ & $5,58 \%$ & 1158 \\
\hline 2017 & $2,01 \%$ & $4,56 \%$ & 1300 \\
\hline 2018 & $1,60 \%$ & $5,09 \%$ & 1599 \\
\hline 2019 & $2,46 \%$ & $5,63 \%$ & 2003 \\
\hline
\end{tabular}

Sumber : Data PT. Bank Mega 2013-2019

\section{Research Method}

\section{Penarikan Sampel dan Pengumpulan Data}

Populasi dalam penelitian ini adalah seluruh laporan keuangan tahunan Bank Mega. Sedangkan dalam penelitian ini sampel yang digunakan adalah laporan keuangan Bank Mega dari 
tahun 2013 sampai dengan tahun 2019. Dalam pengumpulan data, penulis menggunakan beberapa teknik pengumpulan data yaitu Studi Pustaka serta Analisis Laporan Keuangan.

\section{Uji Asumsi Klasik}

Uji Normalitas

Uji Normalitas digunakan untuk menguji apakah variabel residual dalam model regresi mempunyai distribusi normal atau tidak. Uji F dan Uji t mengasumsikan bahwa nilai residual mengikuti distribusi normal. Terdapat dua cara untuk mendeteksi residual berdistribusi normal atau tidak yaitu dengan analisis grafik dan uji statistik. Pengujian ini dilakukan dengan melihat nilai Asymp. Sig. pada hasil uji normalitas dengan menggunakan One Sample KolmogorovSmirnov Test. Ketentuan suatu model regresi berdistribusi secara normal apabila probability dari Kolmogrov-Smirnov lebih besar dari 0,05 (p>0,05) (Djarwanto, 2013).

Uji Multikolinearitas

Cara untuk mendeteksi adanya multikolinearitas dilakukan dengan cara meregresikan model analisis dan melakukan uji korelasi antar variabel independen dengan menggunakan variance inflation factor (VIF) dan tolerance value. Apabila nilai tolerance lebih besar dari 0,1 dan nilai VIF kurang dari 10 maka tidak terdapat multikolinearitas dalam penelitian. Sebaliknya, apabila nilai tolerance kurang dari 0,1 dan nilai VIF lebih besar dari 10 maka terdapat multikolinearitas (Ghozali, 2014)

Uji Heteroskedastisitas

Uji heteroskedastisitas bertujuan untuk menguji apakah dalam model regresi terjadi ketidaksamaan variance dari residual satu pengamatan ke pengamatan yang lain. Jika variance dari residual satu pengamatan ke pengamatan yang lain tetap, maka disebut homoskedastisitas dan jika berbeda disebut heteroskedastisitas. Model regresi yang baik adalah yang homoskedastisitas atau tidak terjadi heteroskedastisitas. Gejala heteroskedastisitas diuji dengan metode Glejser dengan cara menyusun regresi antara nilai absolut residual dengan variabel bebas. Apabila masing-masing variabel bebas tidak berpengaruh signifikan terhadap absolut residual $(\alpha=0,05)$ maka dalam model regresi tidak terjadi gejala heteroskedastisitas (Sanusi, 2015).

\section{Analisis Regresi Linier Berganda}

Analisis regresi merupakan studi mengenai ketergantungan variabel dependen dengan satu atau lebih variabel independent (Ghozali, 2014). Penelitian ini bertujuan untuk menganalisis pengaruh variabel bebas (independen) tingkat Non Performing Loan pada Bank Mega (X1) dan Tingkat suku bunga Bank Indonesia (X2) terhadap variabel tak bebas (dependen) yaitu Laba bersih Bank Mega dari tahun 2014 sampai tahun 2018. Bentuk analisis regresi linier berganda ini mempunyai bentuk umum persamaan sebagai berikut:

$$
\mathrm{Y}=\mathrm{a}+\mathrm{b} 1 \mathrm{X} 1+\mathrm{b} 2 \mathrm{X} 2+\mathrm{e}
$$

\section{Uji t}

Uji statistik t menunjukkan seberapa jauh pengaruh masing-masing variabel independen secara individu dalam menerangkan variasi variabel dependen. Uji t digunakan untuk menguji signifikasi pengaruh masing-masing variabel independen terhadap variabel dependen. Pengujian ini menggunakan level of significant $(\alpha) 0,05$.

\section{Results and Analysis}




\subsection{Uji Asumsi Klasik}

Sebelum melakukan analisa regresi berganda diperlukan untuk melakukan uji asumsi klasik, hal ini dilakukan untuk menguji apakah persamaan yang kita gunakan berdistribusi dengan normal atau tidak, jika data berdistribusi dengan normal artinya data yang kita gunakan layak untuk dilakukan uji regresi linear berganda.

\section{a. Uji Normalitas}

Tabel 2. Tabel Kolmogorov-Smirnov Test

\begin{tabular}{|ll|r|}
\hline & & $\begin{array}{r}\text { Unstandardiz } \\
\text { ed Residual }\end{array}$ \\
\hline $\mathrm{N}$ & Mean & 7 \\
Normal Parameters & a,b &, 0000000 \\
Most Extreme Differences & Std. Deviation & 412,2365449 \\
& Absolute &, 210 \\
& Positive &, 210 \\
Test Statistic & Negative &,- 122 \\
Asymp. Sig. (2-tailed) & &, 210 \\
\hline
\end{tabular}

Sumber: Olahan SPSS

Dari hasil spss uji Kolmogorov-Smirnov diatas menunjukkan nilai Asymp. Sig. (2-tailed) sebesar 0,200 yang lebih besar dari 0,05 ini menunjukkan bahwa data-data di dalam penelitian ini berdistribusi dengan normal, dengan demikian asumsi atau persyaratan normalitas dalam model regresi sudah terpenuhi.

Gambar 2. Uji Normalitas Probability P-Plot

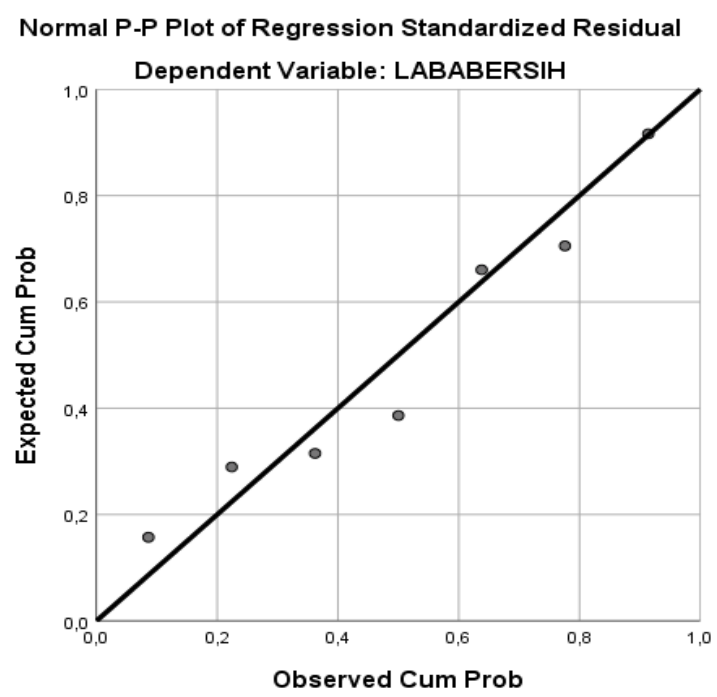

Sumber : Olahan SPSS

Dari gambar 2 di atas juga mempertegas bahwa model regresi yang diperoleh berdistribusi normal, dimana sebaran data berada di sekitar garis diagonal.

\section{b.Uji Multikolinearitas}

JURNAL ILMIAH KOMPUTERISASI AKUNTANSI Vol. 14, No. 2, Desember $2021: 373-382$ 
Tabel 3.

Tabel Uji Multikolinearitas

\begin{tabular}{|c|c|c|c|c|c|c|c|c|}
\hline \multicolumn{9}{|c|}{ Coefficients $^{\mathrm{a}}$} \\
\hline \multirow[b]{2}{*}{ Model } & & \multicolumn{2}{|c|}{ Unstandardized Coefficients } & \multirow{2}{*}{$\begin{array}{c}\begin{array}{c}\text { Standardized } \\
\text { Coefficients }\end{array} \\
\text { Beta }\end{array}$} & \multirow[b]{2}{*}{$t$} & \multirow[b]{2}{*}{ Sig. } & \multicolumn{2}{|c|}{ Collinearity Statistics } \\
\hline & & $B$ & Std. Error & & & & Tolerance & VIF \\
\hline 1 & (Constant) & 2748,823 & 1244,499 & & 2,209 &, 092 & & \\
\hline & NPL & 83,879 & 349,446 &, 095 &, 240 &, 822 &, 956 & 1,046 \\
\hline & SUKUBUNGABI & $-293,054$ & 181,463 &,- 642 & $-1,615$ &, 182 &, 956 & 1,046 \\
\hline
\end{tabular}

Sumber: Data Olahan

Dari tabel diatas nilai VIF variabel NPL dan Suku Bunga BI sebesar 1,046 yang lebih kecil dari 10,00. Maka mengacu pada dasar pengambilan keputusan dalam uji multikolinearitas dapat disimpulkan bahwa tidak ada gejala multikolinearitas dalam model regresi.

\section{c.Uji Heteroskedastisitas}

Tabel 4. Tabel Uji Heterokedastisitas

\begin{tabular}{|c|c|c|c|c|c|c|}
\hline \multicolumn{7}{|c|}{ Coefficients $^{\mathrm{a}}$} \\
\hline \multirow{2}{*}{\multicolumn{2}{|c|}{ Model }} & \multicolumn{2}{|c|}{ Unstandardized Coefficients } & \multirow{2}{*}{$\begin{array}{c}\begin{array}{c}\text { Standardized } \\
\text { Coefficients }\end{array} \\
\text { Beta }\end{array}$} & \multirow[b]{2}{*}{$\mathrm{t}$} & \multirow[b]{2}{*}{ Sig. } \\
\hline & & $B$ & Std. Error & & & \\
\hline \multirow[t]{3}{*}{1} & (Constant) & 437,900 & 577,974 & & ,758 & 491 \\
\hline & NPL & 31,806 & 162,291 &, 099 & 196 & 854 \\
\hline & SUKUBUNGABI & $-29,195$ & 84,275 &,- 174 &,- 346 & ,746 \\
\hline
\end{tabular}

Sumber: Data Olahan

Dari data tabel di atas didapatkan bahwa nilai Sig. variabel Laba bersih sebesar 0,491 yang lebih besar dari 0,05 artinya tidak terjadi gejala heterokedastisitas pada variabel laba bersih.

Hal ini berlaku sama pada variabel NPL dengan Sig. 0,854 yang lebih besar dari 0,05 dan variabel Suku Bunga BI dengan Sig. 0,746 yang juga lebih besar dari 0,05.

Dengan demikian dapat disimpulkan bahwa tidak terjadi gejala heterokedastisitas pada variabel NPL, Suku Bunga BI dan Laba Bersih Bank Mega. 


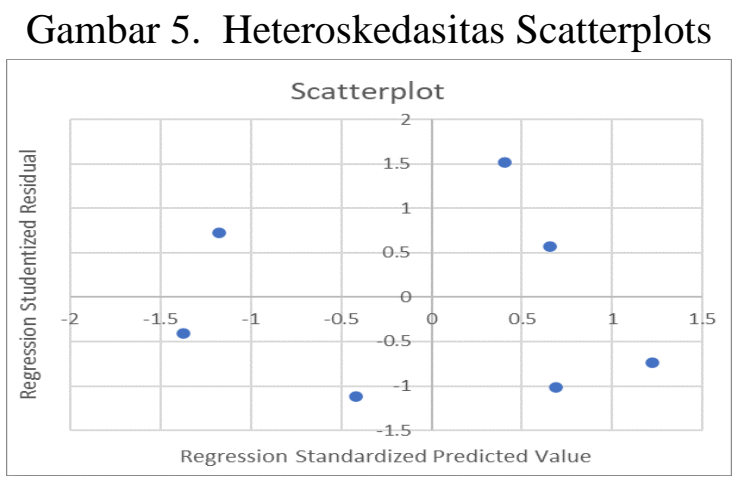

Dari grafik Scatterplot terlihat bahwa titik menyebar tidak beraturan di atas dan di bawah sumbu 0 pada sumbu Y, ini artinya adalah tidak terdapat gejala heterokedastisitas.

\subsection{Analisa Data dan Pembahasan}

1. Uji t Pengaruh antara Non Performing Loan (NPL) terhadap Laba bersih

Tabel 5. Tabel Coefficients

Coefficients $^{\mathrm{a}}$

\begin{tabular}{|c|c|c|c|c|c|c|}
\hline \multirow[b]{2}{*}{ Mode } & & \multicolumn{2}{|c|}{ Unstandardized Coefficients } & \multirow{2}{*}{$\begin{array}{c}\begin{array}{c}\text { Standardized } \\
\text { Coefficients }\end{array} \\
\text { Beta } \\
\end{array}$} & \multirow[b]{2}{*}{$\mathrm{t}$} & \multirow[b]{2}{*}{ Sig. } \\
\hline & & $B$ & Std. Error & & & \\
\hline \multirow[t]{3}{*}{1} & (Constant) & 2748,823 & 1244,499 & & 2,209 &, 092 \\
\hline & NPL & 83,879 & 349,446 &, 095 &, 240 &, 822 \\
\hline & SUKUBUNGABI & $-293,054$ & 181,463 &,- 642 & $-1,615$ & 182 \\
\hline
\end{tabular}

a. Dependent Variable: LABABERSIH

Sumber: Data Olahan

Dari tabel 5 didapatkan nilai signifikansi (Sig.) variabel NPL sebesar 0,822 yang lebih besar dari tingkat signifikansi sebesar 0,05 dan didapatkan juga nilai thitung NPL sebesar 0,240 yang lebih kecil dari ttabel sebesar $2,015(\alpha=5 \% / 2 ; \mathrm{df}=7-2)$ ini artinya secara parsial tidak ada pengaruh yang signifikan antara variabel NPL terhadap variabel Laba bersih Bank Mega.

Dengan demikian, dapat disimpulkan hasil SPSS untuk rumusan masalah pertama yang berbunyi "Bagaimanakah Pengaruh Non Performing Loan (NPL) terhadap Laba bersih Bank Mega dari tahun 2013 sampai tahun 2019?" dengan hipotesis sebagai berikut:

H0: $\quad$ Non Performing Loan (NPL) Tidak berpengaruh terhadap Laba bersih Bank Mega.

H1 : $\quad$ Non Performing Loan (NPL) Berpengaruh terhadap Laba bersih Bank Mega.

Hasilnya adalah H0 ditolak, dan Ha diterima, artinya adalah Non Performing Loan (NPL) Tidak berpengaruh terhadap Laba bersih Bank.

Hal ini dikarenakan tingkat NPL Bank Mega dalam kurun waktu 2013 sampai dengan 2019 berada dibawah 5\%, sedangkan menurut hasil wawancara, NPL baru akan berpengaruh secara tidak langsung terhadap laba bersih bank jika angkanya melebihi 5\%, selain itu juga disebabkan oleh adanya tindakan pencegahan dari bank itu sendiri berupa penerapan prinsip $5 \mathrm{C}$ sebelum memberikan pinjaman dana kepada nasabah tertentu yang di dalamnya terdapat Collateral, yaitu studi aspek kelayakan sebuah barang jaminan atau agunan milik nasabah pemohon pinjaman dana

JURNAL ILMIAH KOMPUTERISASI AKUNTANSI Vol. 14, No. 2, Desember $2021: 373-382$ 
tersebut, serta adanya tindakan pencegahan lainnya seperti mengasuransikan nasabah yang meminjam dana, sehingga NPL cenderung memiliki dampak yang minim terhadap laba bersih bank jika angkanya tidak melebihi batasan aturan OJK, jadi NPL tidak akan berpengaruh terlalu signifikan terhadap laba bersih Bank Mega selama tingkat NPL tersebut berada di angka yang wajar, selain itu perlu diingat bahwa pembiayaan bukanlah satu-satunya sumber pendapatan bank, masih ada sumber pendapatan lainnya yang memengaruhi laba bersih Bank Mega, seperti investasi dalam surat berharga, kartu kredit, ATM, dan pendapatan operasional lainya.

Penemuan dalam penelitian ini sejalan dengan hasil penelitian yang dilakukan oleh Ayu Shauma Fitriyani (2016), sementara itu penelitian ini juga turut menguatkan hasil penelitian terdahulu oleh Risky Diba Avrita. Irene Rini Demi Pangestusti, (2016) dan Yohan Henri Wibowo (2017).

\section{Uji t Pengaruh Tingkat Suku Bunga Bank Indonesia terhadap Laba Bersih}

Tabel 6. Tabel Coefficients

Coefficients $^{a}$

\begin{tabular}{|c|c|c|c|c|c|c|}
\hline \multirow[b]{2}{*}{ Model } & & \multicolumn{2}{|c|}{ Unstandardized Coefficients } & $\begin{array}{c}\text { Standardized } \\
\text { Coefficients }\end{array}$ & \multirow[b]{2}{*}{$\mathrm{t}$} & \multirow[b]{2}{*}{ Sig. } \\
\hline & & $B$ & Std. Error & Beta & & \\
\hline 1 & (Constant) & 2748,823 & 1244,499 & & 2,209 &, 092 \\
\hline & NPL & 83,879 & 349,446 & .095 &, 240 &, 822 \\
\hline & SUKUBUNGABI & $-293,054$ & 181,463 &,- 642 & $-1,615$ & , 182 \\
\hline
\end{tabular}

a. Dependent Variable: LABABERSIH

Sumber : Data Olahan

Dari tabel 6. didapatkan nilai signifikansi (Sig.) variabel Suku Bunga BI sebesar 0,182 yang lebih besar dari tingkat signifikansi sebesar 0,05 dan dari tabel tersebut didapatkan juga nilai thitung Suku Bunga BI sebesar -1,615 yang lebih kecil dari nilai ttabel sebesar 2,015 $(\alpha=5 \% / 2 ; \mathrm{df}=7-2)$ ini artinya secara parsial tidak ada pengaruh yang signifikan antara variabel NPL terhadap variabel Laba bersih Bank Mega.

Dengan demikian, dapat disimpulkan hasil SPSS untuk rumusan masalah kedua yang berbunyi "Bagaimanakah Pengaruh Tingkat Suku Bunga Bank Indonesia terhadap Laba Bersih Bank Mega dari tahun 2013 sampai tahun 2019?” dengan hipotesis sebagai berikut:

H0 : $\quad$ Tingkat Suku Bunga BI Tidak berpengaruh terhadap Laba bersih Bank Mega.

H1: $\quad$ Tingkat Suku Bunga BI Berpengaruh terhadap Laba bersih Bank Mega.

Hasilnya adalah H0 ditolak, dan Ha diterima, artinya adalah Tingkat Suku Bunga BI Tidak berpengaruh terhadap Laba bersih Bank.

Disamping itu, penelitian ini juga menemukan bahwa tingkat suku bunga Bank Indonesia tidak berpengaruh signifikan terhadap Laba Bersih Bank Mega, hal ini dikarenakan adanya kebijakan penyesuaian dan adaptasi dari Bank Mega itu sendiri terhadap perubahan tingkat suku bunga Bank Indonesia, jika suatu masa tingkat suku bunga tinggi, dan masyarakat akan enggan untuk meminjam dana dari bank, maka bank akan mengalihkan alokasi pembiayaan ke instrumen investasi lainnya yang lebih menguntungkan seperti saham, obligasi, dan lain sebagainya untuk mencegah modal yang menganggur.

PENGARUH NON-PERFORMING LOAN DAN SUKU BUNGA BANK INDONESIA TERHADAP LABA BERSIH PT. BANK MEGA (Lukman Hakim) 
Sementara bunga deposito dan tabungan terus berjalan dan bank juga bisa memperoleh penghasilan dari kegiatan operasional seperti transfer, ATM, giro, kartu kredit dan lain sebagainya,. hal ini juga diperkuat dengan hasil wawancara yang mengatakan bahwa adanya hubungan timbal balik antara surat obligasi maupun instrumen pasar uang lainnya dengan deposito atau tabungan Bank, narasumber menjelaskan bahwa jika pemerintah sewaktu-waktu akan menerbitkan surat obligasi, maka pemerintah akan menurunkan suku bunga untuk deposito dan tabungan di bank agar masyarakat tertarik untuk membeli surat obligasi tersebut, setelah itu pemerintah akan menaikkan suku bunga deposito dan tabungan bank untuk menekan laju inflasi dengan mengurangi jumlah uang yang beredar, maka dari itu bank juga telah mempersiapkan langkah-langkah serta SOP antisipasi terhadap hal-hal tersebut dan pembiayaan bukanlah satusatunya penghasilan dari bank. Jadi dapat di katakan bahwa hasil SPSS dan hasil wawancara memiliki hasil yang searah atau sepemikiran.

Hasil dari penelitian ini tentang hubungan tingkat suku bunga Bank Indonesia terhadap laba bersih Bank Mega juga searah dengan penelitian yang dilakukan oleh Martha Ayerza (2016).

\section{Pengaruh Tingkat Non Performing Loan (NPL) dan Tingkat suku bunga Bank Indonesia secara simultan terhadap Laba Bersih.}

Tabel 7. Tabel Coefficients

Coefficients $^{a}$

\begin{tabular}{|c|c|c|c|c|c|c|}
\hline \multirow{2}{*}{\multicolumn{2}{|c|}{ Model }} & \multicolumn{2}{|c|}{ Unstandardized Coefficients } & \multirow{2}{*}{$\begin{array}{c}\begin{array}{c}\text { Standardized } \\
\text { Coefficients }\end{array} \\
\text { Beta }\end{array}$} & \multirow[b]{2}{*}{$\mathrm{t}$} & \multirow[b]{2}{*}{ Sig. } \\
\hline & & $\mathrm{B}$ & Std. Error & & & \\
\hline \multirow[t]{3}{*}{1} & (Constant) & 2748,823 & 1244,499 & & 2,209 &, 092 \\
\hline & NPL & 83,879 & 349,446 &, 095 &, 240 & 822 \\
\hline & SUKUBUNGABI & $-293,054$ & 181,463 &,- 642 & $-1,615$ & 182 \\
\hline
\end{tabular}

a. Dependent Variable: LABABERSIH

\section{Sumber : Data Olahan}

Dari tabel 7. di atas, didapatkan sebuah persamaan model regresi sebagai berikut:

$Y=2748,823+83,879 X_{1}-293,054 X_{2}$

Dari persamaan regresi di atas dapat disimpulkan bahwa:

a. Nilai konstanta (a) sebesar 2748,823 artinya adalah jika variabel Non Performing Loan (NPL) dan variabel tingkat suku bunga Bank Indonesia sebesar nol (0) maka laba bersih Bank Mega sebesar 2748,823 (Milliar)

b. Nilai koefisien regresi variabel Non Performing Loan (NPL) sebesar 83,879 artinya adalah jika variabel tingkat suku bunga Bank Indonesia tetap dan variabel NPL naik sebesar 1 maka laba bersih Bank Mega akan naik sebesar 83,879.

c. Nilai koefisien regresi variabel Tingkat Suku Bunga Bank Indonesia sebesar 293,054 ini artinya adalah jika variabel NPL tetap dan variabel tingkat suku bunga Bank Indonesia mengalami kenaikan sebesar 1 maka variabel laba bersih Bank Mega akan mengalami penurunan sebesar 293,054. 
Tabel 8. Tabel Model Summary

Model Summary

\begin{tabular}{|l|c|r|r|r|r|}
\hline Model & $\mathrm{R}$ & R Square & $\begin{array}{c}\text { Adjusted R } \\
\text { Square }\end{array}$ & $\begin{array}{l}\text { Std. Error of } \\
\text { the Estimate }\end{array}$ & $\begin{array}{l}\text { Durbin- } \\
\text { Watson }\end{array}$ \\
\hline 1 &, $629^{\mathrm{a}}$ &, 396 &, 093 & 504,885 & 1,030 \\
\hline
\end{tabular}

a. Predictors: (Constant), SUKUBUNGABI, NPL

b. Dependent Variable: LABABERSIH

Sumber: Data Olahan

Dari tabel 8. , didapatkan nilai Adjusted $R$ Square sebesar 0,093 ini artinya variabel NPL dan Tingkat suku bunga BI secara simultan (bersama-sama) memiliki pengaruh sebesar 9,3\% terhadap Laba bersih Bank Mega, dan sisa 90,7\% dipengaruhi oleh variabel-variabel tidak diketahui lainnya yang tidak dimasukan didalam penelitian ini.

Tabel 9. Tabel Anova

\begin{tabular}{|c|c|c|c|c|c|c|}
\hline \multicolumn{7}{|c|}{ ANOVA $^{a}$} \\
\hline \multicolumn{2}{|c|}{ Model } & $\begin{array}{l}\text { Sum of } \\
\text { Squares }\end{array}$ & df & Mean Square & $\mathrm{F}$ & Sig. \\
\hline \multirow[t]{3}{*}{1} & Regression & 667421,615 & 2 & 333710,808 & 1,309 &, $365^{b}$ \\
\hline & Residual & 1019633,814 & 4 & 254908,453 & & \\
\hline & Total & 1687055,429 & 6 & & & \\
\hline
\end{tabular}

Sumber: Data Olahan

Dari tabel anova di atas di dapatkan nilai Sig. sebesar 0,365 yang lebih besar dari nilai tingkat signifikansi yakni sebesar 0,05. Maka ini berarti bahwa variabel NPL dan Tingkat suku BI tidak mempengaruhi Laba Bersih Bank Mega secara simultan atau bersamaan.

Dan jika dilihat dari tabel tersebut didapatkan nilai $F_{\text {hitung }}$ sebesar 1,309 yang lebih kecil dari nilai $F_{\text {tabel }}$ sebesar 6,94 (dengan df: $\alpha,(k-1)$, (n-k) atau df: 0,05 (3-1), (7-3)) maka ini berarti bahwa variabel NPL dan Tingkat suku BI tidak mempengaruhi Laba Bersih Bank Mega secara simultan atau bersamaan.

Dengan demikian, dapat disimpulkan hasil SPSS untuk rumusan masalah ketiga yang berbunyi "Bagaimanakah Pengaruh Non Performing Loan (NPL) dan Tingkat Suku Bunga Bank Indonesia secara simultan terhadap Laba Bersih Bank Mega dari tahun 2013 sampai tahun 2019?" dengan hipotesis sebagai berikut:

H3o: $\quad$ Non Performing Loan (NPL) dan Tingkat Suku Bunga BI Tidak berpengaruh secara simultan terhadap Laba bersih Bank Mega.

H3a : $\quad$ Non Performing Loan (NPL) dan Tingkat Suku Bunga BI Berpengaruh secara simultan terhadap Laba bersih Bank Mega.

Hasilnya adalah H3a ditolak, dan H3o diterima, artinya adalah Non Performing Loan (NPL) dan Tingkat Suku Bunga BI Tidak berpengaruh secara simultan terhadap Laba bersih Bank Mega. 


\section{Conclusion}

Tingkat Non Performing Loan (NPL) tidak berpengaruh signifikan terhadap Laba Bersih Bank Mega. Hal ini dikarenakan tingkat NPL Bank Mega dalam kurun waktu 2013 sampai dengan 2019 berada dibawah 5\%, Tingkat Suku Bunga Bank Indonesia tidak berpengaruh signifikan terhadap Laba Bersih Bank Mega. hal ini dikarenakan adanya kebijakan penyesuaian dan adaptasi dari Bank Mega itu sendiri terhadap perubahan tingkat suku bunga Bank Indonesia, jika suatu masa tingkat suku bunga tinggi, dan masyarakat akan enggan untuk meminjam dana dari bank, maka bank akan mengalihkan alokasi pembiayaan ke instrumen investasi lainnya yang lebih menguntungkan seperti saham, obligasi, dan lain sebagainya untuk mencegah modal yang menganggur sementara bunga deposito dan tabungan terus berjalan dan bank juga bisa memperoleh penghasilan dari kegiatan operasional seperti transfer, ATM, giro, kartu kredit dan lain sebagainya,

\section{References}

Ayerza, M. (2018). Analisis Pengaruh Tingkat Suku Bunga dan Inflasi Terhadap Profitabilitas Perbankan Yang Terdaftar Di Bursa Efek Indonesia. Jakarta: Institut Bisnis dan Informatika Kwik Kian Gie. 2018.

Djarwanto. (2013). Pokok Analisis Laporan Keuangan. Yogyakarta : BPFE UGM.

Fitriyan, A. S. ( 2016). Pengaruh Non Performing Loan (Npl)terhadap Laba Pada PT. Bank Rakyat Indonesia (Persero) Tbk Unit Karanganyar Kantor Cabang Tegal. Tegal: Politeknik Harapan Bersama.

Ghozali, I. (2014). Aplikasi Analisis Multivariate Dengan Program SPSS. Jakarta.

Riyadi, S., Iqbal, M., \& Lauren, N. (2015). Strategi Pengelolaan Non Performing Loan Bank Umum yang Go Public. Jurnal Dinamika Manajemen.

Sanusi, A. (2015). Metode Penelitian Bisnis. Yogyakarta.

Sudirman, W. (2011). Kebijakan Fiskal dan Moneter. Jakarta: Kencana.

Warjiyo, P., \& Solikin. (2003). Kebijakan Moneter di Indonesia. Jakarta: PPSK.

Wibowo., Y. H. (2017). Hubungan Antara Rasio Kredit Bermasalah dengan Rasio Profitabilitas: Studi Empiris pada BPR Se-Kota Tangerang Periode 2015 . Jakarta: Fakultas Ekonomi, Universitas Islam Attahiriyah. 